\title{
Technical And Economic Analysis Of Catching Equipment Totaluo In Nike Fishing (Awaous Melanocephalus) In Gorontalo City
}

\author{
Tineke Wolok ${ }^{1}$, Zhulmaydin Chairil Fachrussyah ${ }^{2}$, Irwan Yantu ${ }^{3}$ \\ ${ }^{2}$ Department of Aquatic Resource Management, Faculty of Fisheries and Marine Sciences, \\ Gorontalo State University \\ ${ }^{1,2}$ Department of Management, Faculty of Economics, Gorontalo State University \\ E-Mail: fachrussyah@ung.ac.id
}

\begin{abstract}
:
This study aims to describe totaluo and describe the feasibility status of nike (Awaous melanocephalus) fishing businesses using totaluo. This research was conducted in Gorontalo City in December 2018-February 2019. The analysis used in this study was descriptive analysis, cost analysis and R / C Ratio analysis. The results showed that Totaluo is shaped like two triangles which are joined together at one end and are equipped with nails. If observed, totaluo is similar to other types of fishing gear included in the Scoop net category. R / C Ratio analysis got a value of 2.68 so that the nike fishing business (Awaous melanocephalus) using totaluo could be declared feasible to be carried out / continued because the R / C Ratio value> 0
\end{abstract}

\section{Keywords: Totaluo; Fish; Nike; Cost}

Nike (Awaous melanocephalus) is one type of fish caught in the southern waters of Gorontalo including Gorontalo City. This fish is a type of fish that is small in size between 2 to $4 \mathrm{~cm}$, and has its own uniqueness because of its emergence cycles in large numbers in one particular location (Yusuf, 2011). Nike is an endemic species in the Gorontalo region. This fish has a maximum body size of $\pm 8 \mathrm{~cm}$. Fish that are smaller than anchovy have their own uniqueness, namely the emergence cycle occurs in large numbers in one particular location found in the waters around the mouth of the Bone River. This nike fishing area is usually in the coastal area around the North Leato Village and Tanjung Kramat Village and only appears at the end of the Qomariah Year (Mohammad, 2015)

In an effort to capture him, nike (Awaous melanocephalus) by fishermen captured with several fishing gear depends on his fishing area (Fachrussyah, 2019) including using totaluo. Totaluo is a naming by fishermen carried out by local fishermen so that this name continues to be used today. 
Until now, the production of nike (Awaous melanocephalus) has been increasing and abundant (Tuina, 2014) including those caught by fishermen using totaluo. This condition continues to occur until now, where totaluo remains one of the fishing tools that the majority are used by fishermen.

Therefore, it is important to carry out research related to totaluo and nike fishing (Awaous melanocephalus) using totaluo. In this study, the researchers aimed to describe totaluo and describe the feasibility status of nike fishing (Awaous melanocephalus) using totaluo.

\section{METHOD}

This research was conducted in December 2018 until February 2019 in Gorontalo City. The method used in this research is experimental fishing which is carried out by catching nike (Awaous melanocephalus) directly with business people (Fishermen). The sampling selection method uses a purposive sampling method. The sampling chosen was the respondents (fishermen) who were willing to do it as a media and research tool.

The data collected is obtained from direct observation in the field and comes from questionnaires and interviews conducted to fisheries business actors. The data obtained were analyzed by the following methods:

1. Descriptive Analysis. Descriptive analysis was carried out to describe the technical aspects of nike fishing
(Awaous melanocephalus) which included: Construction Details and totaluo operating techniques.

2. Business Feasibility Analysis. The Business Feasibility Analysis was conducted to describe the feasibility of nike (Awaous melanocephalus) fishing businesses using totaluo.

\section{Revenue Analysis}

Income analysis aims to find out how high the business level is and to find out how much income the fishermen will get from fishing gear applications (Haspari et all, 2016), and calculated based on the following formula the following formula:

$\mathrm{TR}=\mathrm{P} \times \mathrm{Q}$.

Information:

$\mathrm{TR}=$ Total Revenue

$\mathrm{P}=$ Market price

$\mathrm{Q}=$ Production

\section{Cost Analysis}

Cost Analysis is an analysis to calculate the total costs used in fishing operations. According to Rantung et all (2015) these costs are calculated using the following formula:

$\mathrm{TC}=\mathrm{FC}+\mathrm{VC}$

Information:

$\mathrm{TC}=$ total cost

$\mathrm{FC}=$ Fix cost (costs that do not change, regardless of the product produced, which is also known as indirect costs)

$\mathrm{VC}=$ variable cost (fees vary depending on the amount produced, also called direct cost)

\section{Analysis of Profit and Loss}

Analysis of profit and loss (profit) is an analysis used to determine the condition of 
business profits. According to Gupito et all, the income statement analysis is calculated using the following formula:

$\mathrm{I}=\mathrm{TR}-\mathrm{TC}$

Information:

I $=$ Net income

TC $=$ total cost

$\mathrm{TR}=$ Total Revenue

A business or business is declared feasible if $\mathrm{I}>0$. If $\mathrm{I}<0$ a business or business is declared to be inadequate, if $\mathrm{I}=0$ the business is declared break-even (Mamondol, 2016)

\section{R / C Ratio Analysis}

Mamondol (2016) says that R / C Ratio is a ratio or ratio between total revenue and

\section{RESULTS AND DISCUSSION}

\section{Technical Aspects}

Description and Construction of Totalou

Totaluo is one type of fishing gear used by local people to catch nike (Awaous melanocephalus). Totaluo is shaped like two triangles which are joined total production costs which are mathematically expressed by the formula:

$\mathrm{R} / \mathrm{C}$ Ratio $=\mathrm{TR} / \mathrm{TC}$

A business or business is declared feasible if R / C Ratio> 0. If the R / C Ratio $<0$ business or business is declared not feasible, whereas if the $\mathrm{R} / \mathrm{C}$ Ratio $=0$ the business is declared break even. The greater the value of $\mathrm{R} / \mathrm{C}$ Ratio, the business or business will be more profitable, because the revenue obtained by producers from each expenditure of production costs of 1 unit will be even greater (Fitriadi and Nurmalina, 2008).

together at one end and are equipped with nails. If observed, totaluo is similar to other types of fishing gear included in the Scoop net category. Fachrussyah (2017) says that Scoop net is a part of Lift net when viewed from the perspective of the operating technique. More details about totaluo can be seen in the following picture:

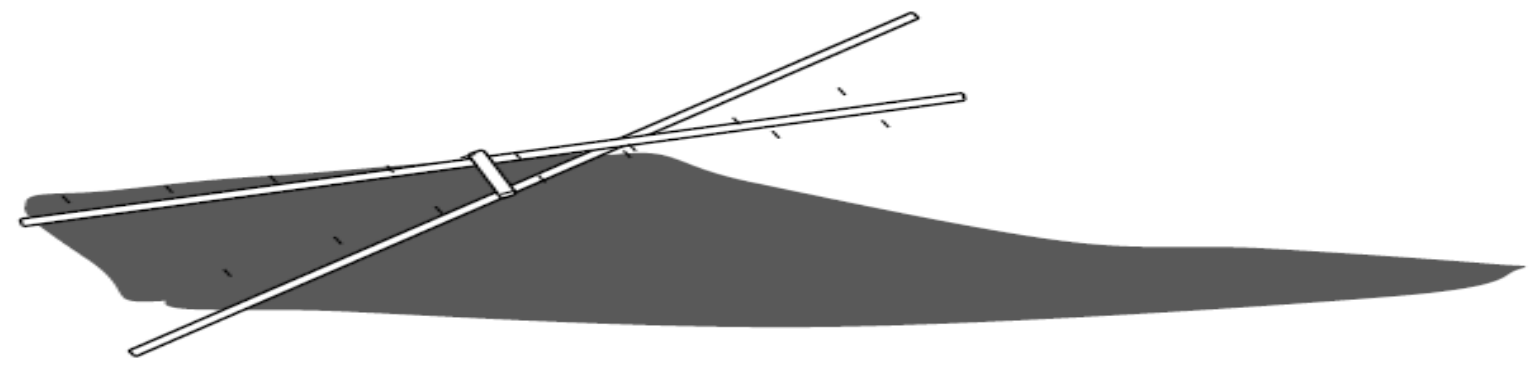

Figure 1. Totaluo

Totaluo construction consists of 2 parts, namely the stalk which functions as a frame, and the net. The tank used can be made of wood, rattan or bamboo, but the majority of the people who catch nike 'use bamboo as their stalk. Babu is used with a 
diameter of $3 \mathrm{~cm}$ with a length of $210 \mathrm{~cm}$ consisting of $170 \mathrm{~cm}$ frame length and the remaining $40 \mathrm{~cm}$ as a base for holding. The net used in totaluo is similar to the net used in nike nets. The nets are made from netting without knots (knotless).

\section{Totaluo operation}

The nike capture technique using this fishing gear is very simple and flexible. The operation of totaluo is done by pushing totaluo into the water. Similarly, the other scoop net functions to take fish from the net after hauling, in other words, it can be used to move the catch to a fish shelter (container).

Totaluo's operation was carried out at the front of the boat. The lights are turned on to collect nike fish around the boat. After the nike has gathered, totaluo is slowly lowered and immediately lifted again. When fishing gear approaches the surface, the speed of capture is increased even more. More details can be seen in the following picture:

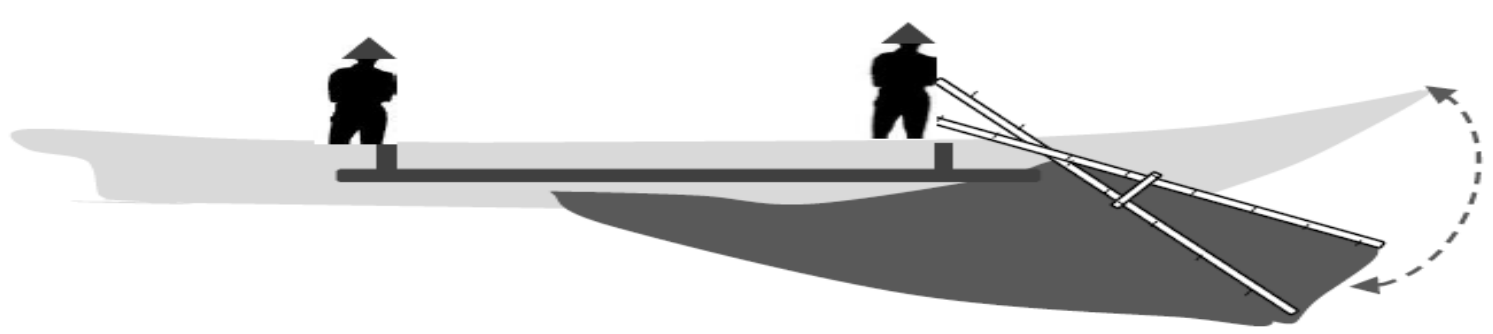

\section{Economic aspects}

Investation

According to Sari et all (2018)

Calculation of the cost of fixed capital investment is the estimate of funds issued as a result of the realization of pre-mining activities that include managing permits,
Figure 2. Totaluo's operation uses a boat

exploration activities, preparing technical documents, infrastructure construction costs, purchasing equipment, etc. until mining project activities are ready do. In fishing business using totaluo investment costs within a period of 1 year are displayed in the following table:

Table 1. Investment costs for fishing business using totaluo

\begin{tabular}{lr}
\hline \multicolumn{1}{c}{ ITEM } & COST (IDR) \\
\hline Ship & $5,000,000$ \\
Machine & $4,500,000$ \\
Totaluo (Fishing Gear) & 500,000 \\
Box & 50,000
\end{tabular}


Source: Field Data (2019)

The investment cost in table 1 above is a cost that must be prepared to carry out a business of fishing using totaluo for 1 year. Fixed costs include the cost of purchasing/manufacturing boats, engines, fishing gear, fish storage boxes, generators and lights and equipment.

\section{Income and Profit and Loss}

Analysis of income is the proceeds of business people (fishermen) in doing business. Especially for catching nike (Awaous melanocephalus), income is the product of the catch between fish and prices on the market. In this study, fish caught and sold were only nike (Awaous melanocephalus).

In the sale of nike (Awaous melanocephalus), fishermen in Gorontalo
City use a bucket / box unit in their calculations. In 1 (one) year of arrest, the average fisherman gets 40 (forty) buckets with an average selling price of Rp. 750,000 / bucket if sold on the market. So in 1 (One) Year of arrest, fishermen get Rp. 30,000,000

Costs incurred to conduct a nike fishing business for 1 (One) Year include fixed costs and non-fixed costs. Fixed costs in this business are depreciation costs of the value of investment and maintenance costs, while for non-fixed costs include fuel costs, consumption and other needs. More details can be seen in the following table

Table 2. Costs for nike fishing businesses using totaluo

\section{ITEM}

COST (IDR)

\section{Fixed Cost}

A Depreciation Cost (IDR)

Ship

Machine

Totaluo (Fishing Gear)

Box

Lamp and equipment

Genset

B Maintenance

Ship

Machine
$\mathrm{Rp}$ 500,000

$\mathrm{Rp}$

750,000

$\mathrm{Rp}$

$\mathrm{Rp}$

50,000

5,000

Rp

50,000

Rp

350,000

500,000

$\mathrm{Rp}$

$1,000,000$ 
Totaluo (Fishing Gear)

Lamp and equipment

\section{Total Fixed Cost}

\section{Variable Cost (IDR)}
a. Fuel
b. Consumption
c. Cigarette

Total Variable Cost

$\begin{array}{lr}\text { Rp } & 100,000 \\ \text { Rp } & 100,000 \\ \text { Rp } & \mathbf{3 , 4 0 5 , 0 0 0}\end{array}$

Rp $\quad 5,400,000$

Rp $\quad 600,000$

$\mathrm{Rp} \quad 1,800,000$

Rp
Source: Field Data (2019)

Based on the table above, it can be seen that the total cost of nike (Awaous melanocephalus) fishing business using totaluo is Rp. 11,205,000 consisting of a fixed fee of Rp. 3,405,000 and the fee is not but Rp. 7,800,000

Based on the results of the calculation above, it can be calculated that the Nike fishing business (Awaous melanocephalus) using totaluo gets a profit of Rp. 18,795,000 / year resulting from a reduction between the total income of $\mathrm{Rp}$.
$30,000,000$ reduced by a total cost of $\mathrm{Rp}$. $11,205,000$. This condition can be said that the nike (Awous sp) fishing business is feasible because of Advantage (I) $>0$.

\section{R / C Ratio Analysis}

$\mathrm{R}$ / C Ratio analysis is intended to find out the comparison between costs incurred with income received. Nike fishing (Awaous melanocephalus) using totaluo in Gorontalo City based on R / C Ratio analysis gets a value of 2.68 , more clearly can be seen in the following table:

Table 3. Analysis of R / C Ratio of nike fishing businesses using totaluo

Total Revenue (IDR) $\quad$ Total Cost (IDR) $\quad$ R/C Ratio

$$
30.000 .000
$$

11.205 .000

2.68

Source: Data analysis (2019)

Based on the table above, it can be concluded that the Nike fishing business (Awaous melanocephalus) using totaluo can be declared feasible to be carried out / continued because the R / C Ratio value> 0

\section{CONCLUSION}

Based on the research carried out, the following conclusions were obtained:
1. Totaluo is shaped like two triangles which are joined together at one end and are equipped with nails. If observed, totaluo is similar to other types of fishing gear included in the Scoop net category. Totaluo construction consists of 2 parts, namely the stalk which functions as a frame, and the net. The tank used can be made of wood, rattan or bamboo, 
but the majority of the people who catch nike 'use bamboo as their stalk. Babu is used with a diameter of $3 \mathrm{~cm}$ with a length of $210 \mathrm{~cm}$ consisting of $170 \mathrm{~cm}$ frame length and the remaining $40 \mathrm{~cm}$ as a base for holding.

2. Within 1 (one) year of arrest, the average fisherman gets 40 (forty) buckets with an average selling price of Rp. 750,000 / bucket if sold on the market. So in 1 (One) Year of arrest, fishermen get Rp. 30,000,000. Nike (Awous sp) fishing using totaluo in Gorontalo City based on R / C Ratio analysis got a value of 2.68 so that the nike fishing business (Awaous melanocephalus) using totaluo could be declared feasible to be carried out / continued because the R / C Ratio> 0

\section{REFERENCES}

Fachrussyah, Z. C. (2017). Buku Ajar Dasar Dasar Penangkapan Ikan. MAKALAH, 2(1354).

Fitriadi, F. dan R. Nurmalina, 2008. Analisis Pendapatan dan Pemasaran Padi Organik Metode System of Rice Intensification (SRI): Kasus di Desa Sukagalih, Kecamatan Sukaratu, Kabupaten Tasikmalaya). Jurnal Pengkajian dan Pengembangan Teknologi Pertanian. 11 (1): 94 103.

Gupito, R. W., Irham, I., \& Waluyati, L. R. (2014). Analisis Faktor-Faktor Yang Mempengaruhi Pendapatan Usahatani Sorgum Di Kabupaten Gunungkidul. Agro Ekonomi, 25(1).Hapsari, T. D., \&
Fitri, A. D. P. (2016). Technical and Economic Analysis of Modified Payang Fishing Gear in the Fishing Port of Tawang Beach in Kendal District, Indonesia. Aquatic Procedia, 7, 254-264.

Mamondol, M. R. (2018). Analisis Kelayakan Ekonomi Usahatani Padi Sawah Di Kecamatan Pamona Puselemba.Rantung, H. A., Pakasi, C. B., \& Talumingan, C. (2015, May). Analisis Struktur Biaya dan Efisiensi Pada Agroindustri Bawang Goreng "UD. Sri Rejeki” Di Kota Palu Provinsi Sulawesi Tengah. In COCOS (Vol. 6, No. 9).

Mohamad, N,W.(2015). Analisis Kandungan Merkuri ( $\mathrm{Hg}$ ) pada Ikan Nike (Awaous melanocephalus) di Wilayah Penangkapan Ikan Nike Kelurahan Leato Utara Kota Gorontalo Provinsi Gorontalo. Skripsi. Universitas Negeri Gorontalo. Gorontalo

Sari, C. F. K., Sawaki, M. E., \& Sabarofek, M. S. (2018). Pengaruh analisis investasi terhadap kelayakan penambangan batu mangan di pt. Berkat esa mining. SCIENCE TECH: Jurnal Ilmiah Ilmu Pengetahuan dan Teknologi, 4(1), 11-18.

Tuina, F. (2014) Penentuan Lama Pengeringan Dan Laju Perubahan Mutu Nike (Awaous Melanocephalus) Kering. Skripsi. Universitas Negeri Gorontalo

Yusuf N. (2011). Rakarakterisasi Gizi Dan Pendugaan Umur Simpan Savory Chips Ikan Nike (Awaous melanocephalus). Thesis. Institut Pertanian Bogor. Bogor. 